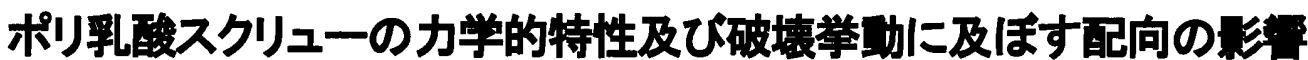

\author{
坂口雅人 ${ }^{* 1}$ ，小林訓史 ${ }^{* 2}$
}

\section{Effect of Orientation on Mechanical Properties and Destruction Behavior of Poly(lactic acid) Screws}

\author{
Masato SAKAGUCHI ${ }^{* 3}$ and Satoshi KOBAYASHI \\ *3 Tokyo Metropolitan Univ. Dept. of Mechanical Engineering \\ Minamiosawa 1-1, Hachioji, Tokyo, 192-0397 Japan
}

\begin{abstract}
Effects of extrusion ratio (ER) and lubricant during extruding on mechanical properties and fracture behavior of poly(lactic acid) (PLA) screws were investigated in terms of shear strength and acoustic emission (AE). Self-reinforced PLA screws were manufactured from axially extruded PLA billets by forging. Shear strength for PLA screw increased by drawing. The result suggested that drawing is effective method to improve shear strength for PLA screws. This might be due to orientation of molecular chains during drawing. Shear strength did not increase linearly with ER, and shear strengths for screw extruded at low ER were slightly higher than that for screw extruded at high ER. This might be due to molecular orientations for screw extruded at high ER were lower than that for screw extruded at low ER. From AE measurement, $\mathrm{AE}$ event occurred in the specimens with extrusion was lower compared to that without extrusion, whereas $\mathrm{AE}$ energy was higher. This suggested that the number of micro-damages which occurred in extruded specimen was fewer and the size of micro-damages was larger.
\end{abstract}

Key Words : Biomaterials, Strength, Screw, Poly-L-lactide, Acoustic Emission, Molding Condition

1. 楼

ポリ乳酸 (PLA)は他の生分解性高分子材料と比較して 高い力学的特性があり, 人体に無害な乳酸に分解される. このため PLA は生体吸収性骨固定デバイスとして研究, 臨床応用されてきたた ${ }^{(12)}$. しかし，PLA 骨固定デバイスの 力学的特性は高負荷部位での固定には不十分であること が報告されている(1,3). PLAの力学的特性を向上させる手 法として延伸による分了鎖の配向か湜案されている( 特にせん断負荷に対する延伸による強化メカニズムは解 明されていない，本研究では延伸が及ぼすせん断強度一 の影響と強化メカニズムを解时するために，PLAスクリ ユ一の力学的特性及ひ破壊挙動に及ぼす配向の影響を調 查した. 延伸条件を変化させて延伸を施したPLA ビレッ トをスクリューに成形し，せん断強度及乙試験時に発生 する Acoustic Emission を測定した.

\section{2. 实的方法}

\section{$2 \cdot 1$ 研究では重量平均分} 子量 95,000, 融点 $169{ }^{\circ} \mathrm{C}$, ガラス転移温度 $73{ }^{\circ} \mathrm{C} の$ PLA ペレットからスクリューを成形した. スクリュ 一の寸法は M6, ネジ部長さ約 $30 \mathrm{~mm}$ の並目ネジで
ある. スクリューの成形は次のような工程で行われ た. 最初にペレットを金型に入れ， $200^{\circ} \mathrm{C}$ で 20 分間 加熱し， $10 \mathrm{MPa}$ の圧力でコールドプレスを行うこと により円筒形ビレットを成形した. このビレットを 押出延伸用の金型とホットプレスを使用して $105{ }^{\circ} \mathrm{C}$ で 10 分間加熱した後，荷重を加えて押出すことによ り延伸を行った．延伸されたビレットには鉎造によ りネジ山が成形された．鍛造ではスクリュー用金型 にビレットをセットし, $120^{\circ} \mathrm{C}$ で 10 分間加熱した後, $200 \mathrm{kN}$ の押切荷重でコールドプレスを行った．その 後, 鍛造により発生するバリをダイスによって取除 くことによって仕上げられた. 本研究は延伸条件と して延伸前後の試験片の断面積の比で定義される延 伸比と潤滑の有無を変化させて延伸を行った．延伸 比は $1 ， 1.3 ， 2 ， 4 ， 8$. 蘭滑剤はポリエチレングリコ 一ルを使用した。

$2 \cdot 2$ せん断式埃スクリューのせん断詿験は 小林 ${ }^{(5)}$ と同じ方法で行った. せん断試験はスクリュー によって結合された治具を島津製作所製，万能詿験 機 (AGS-1000A)を用いてクロスヘッドスピード 0.5

${ }^{* 1}$ 学生員, 首都大学東京 理工学研究科 機械工学専攻

${ }^{* 2}$ 正員, 首都大学東京 (下192-0397 東京都八王子市南大沢 1-1)

E-mail: koba@tmu.ac.jp 
$\mathrm{mm} / \mathrm{min}$ で圧縮することにより行われた. 測定した最 大荷重功以下の式でせん断強度 $S_{s}$ を算出した. $F_{\text {max }}$ は最大荷重, $A$ はスクリューの有効断面積 $\left(22.5 \mathrm{~mm}^{2}\right)$ である.

$$
S_{s}=F_{\text {max }} / 2 A
$$

せん断詿験中の試験片から発生する Acoustic Emission (AE)を測定した。測定にはエヌエフ回路設計ブロック製 の AEセンサー (AE-900M Typel)を使用した。測定条件 はメインアンプのゲイン $30 \mathrm{~dB}$ ，ディスクリローレベル $250 \mathrm{mV}$ ，ディスクリハレベル $375 \mathrm{mV}$ に設定した。

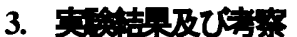

延伸比及ひ㵎滑の有無を変化させて延伸されたスク リューのせん断強度を Fig. 1 に示寸. 潤骬の有無にかか わらず，せん断強度は延伸比 1 と 13 以上を比較すると 延伸によって増加した. これは延伸による分子鎖の配向 によってスクリューのせん断強度が向上することを示唆 している. 延伸比で比較すると，せん断強度は延伸比に 比例しておらず，延伸比 4，8 よりも延伸比 1.3，2 の方 がわずかにせん断強度は高い:これよりせん断能度は延 伸比に比例しないことが示された。これは押出法では延 伸比が低い方がより強く配向するためと考えられる.

Fig. 2 と 3 に延伸比 1 と 13, 潤滑無て延伸されたスク リューのせん断試験におけるせん断応力, 累積 $\mathrm{AE}$ エネ ルギー，累積 $\mathrm{AE}$ イベントと試験時間の関係を示す．延 伸の有無にかかわわらず, 応力 - 試験時間の傾きは約 40 $\mathrm{MPa}$ 以上で減少し，ほほ同時に $\mathrm{AE}$ の発生が見られた。 これより，この点における微小き裂やクレイズのような 微小欠陷の発生が示唆される. $\mathrm{AE}$ は応力の最大值まて増 加し続け，微小欠樎の発生と進展を示唆した. 延伸の有 無で AE の発生挙動を比較すると，延伸された試験片で 発生した AE イベントは延伸比 1 よりも少なく，一方で $\mathrm{AE}$ エネルギーは高い点が挙げられる.これは延伸した試 験片で発生する微小欠陷の数は少ないが, 微小欠陷のサ イズが大きいことを示唆している。

\section{4. 結}

本研究では PLA スクリューの力学的特性及ひ破壊挙 動に及ぼす配向の影響を調查するために，延伸比と潤滑 条件を変化させて延伸を施したスクリューのせん断強度 及び $\mathrm{AE}$ の発生挙動を測定した，その結果，せん断強度 は延伸によって向上することが示唆された。これは延伸 が PLA スクリューのせん断強度を向上させるのに有効 な手段であることを示唆している. 延伸による $\mathrm{AE}$ の発 生挙動を比較すると，延伸を施すことによって発生する
微小欠陥の数は減少するが，微小欠陷のサイズは大きく なることが示唆された。

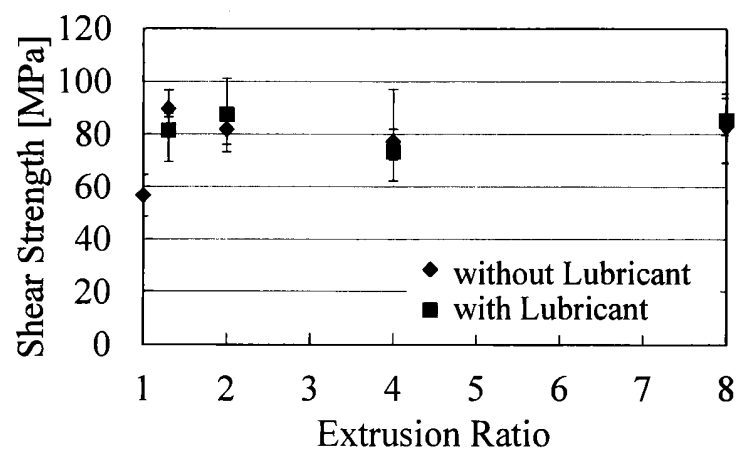

Fig. 1 Shear strength for screws as a function of extrusion ratio

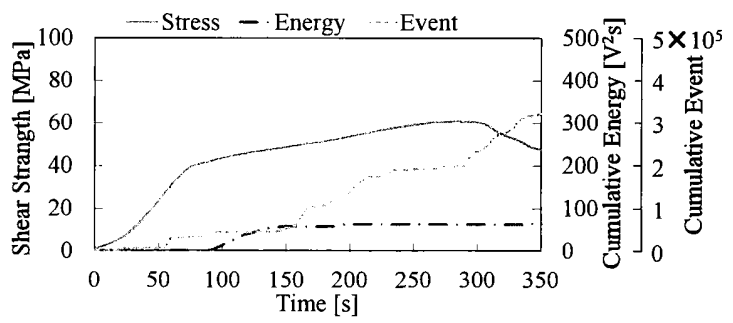

Fig. 2 Relationship between shear stress, cumulative AE energy, event and testing time at extrusion ratio 1 without lubricant

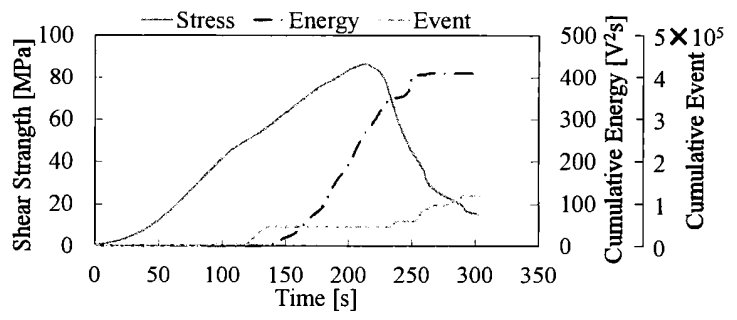

Fig. 3 Relationship between shear stress, cumulative AE energy, event and testing time at extrusion ratio 1.3 without lubricant

\section{文韵}

(1) Manninen, M.J., Self-reinforced poly-L-lactide screws in the fixation of cortical bone osteotomies in rabbits, Journal of Materials Science. Materials in Medicine, Vol. 4 (1993), pp. 179-185.

(2) Bostman, O., Hirvensalo, E., Makinen, J., Rokkanen. P., Foreign-body reactions to fracture fixation implants of biodegradable synthetic polymers, The Journal of Bone and Joint Surgery. British Volume, Vol. 72 (1990), pp. 592-596.

(3) Shetty, V., Caputo, A. A., Kelso, I., Torsion-axial force characteristics of SR-PLLA screws, Journal of Cranio-Maxillofacial Surgery, Vol. 25 (1997), pp. 19-23.

(4) Fengzhe, J., Moon, S. I., Sadami, T., Hyon. S. H., Hydrostatic Extrusion of Poly(L-Lactide), Macromolecular Symposia, Vol. 224 (2005), pp. 93-104.

(5) Satoshi, K., Processing and characterization of forged poly(lactic acid) screw, Materials system, Vol. 29 (2011), pp. 93-99 (in Japanese). 